\title{
Pastorale berading aan persone geaffekteer deur MIV
}

\author{
Authors: \\ Francois G. Minnie ${ }^{1}$ \\ George A. Lotter ${ }^{1}$ \\ Affiliations: \\ ${ }^{1}$ Faculty of Theology, \\ Potchefstroom campus, \\ North-West University, \\ South Africa \\ Correspondence to: \\ Francois Minnie \\ Email: \\ fgminnie@iafrica.com \\ Postal address: \\ PO Box 19343, Noordbrug, \\ 2522, South Africa \\ Dates: \\ Received: 05 Dec. 2011 \\ Accepted: 09 May 2012 \\ Published: 10 Dec. 2012 \\ How to cite this article: \\ Minnie, F.G., Lotter, G.A., \\ 2012, 'Pastorale berading \\ aan persone geaffekteer deur \\ MIV', Koers - Bulletin for \\ Christian Scholarship 77(2), \\ Art. \#59, 8 pages. http:// \\ dx.doi.org/10.4102/koers. \\ v77i2.59
}

C 2012. The Authors.

Licensee: AOSIS

OpenJournals. This work

is licensed under the

Creative Commons

Attribution License.
MIV is ' $n$ pandemie wat elke huishouding in Suid-Afrika, die land met die meeste MIVgeïnfekteerdes in die wêreld, beïnvloed. MIV het 'n geweldige impak op die sosiale, ekonomiese en maatskaplike vlak. Die effek van MIV op die individuele huishoudings word onmiddellik gevoel waar armoede, siekte, spanning rondom die siekbed, dood en eensaamheid die gesin ruk. Die pastorale berader moet met die nodige kennis toegerus wees om die persoon wat geafffekteer is deur MIV, te kan ondersteun en te begelei. Die beradene moet ook toegerus word met die nodige kennis, sodat hy of sy die geïnfekteerde pasiënt kan versorg en begelei en self die spanning en pyn rakende die toestand kan verwerk en hanteer. Riglyne vanuit die Skrif dui aan hoe die Christen sy of haar pyn lyding en dood kan hanteer. In die artikel sal aangedui word hoe die pastorale berader, volgens die Skrif, as geroepe pastor, die beradene moet begelei deur vermaning, bemoediging en ondersteuning om sodanig bemagtig te word om sy of haar krisisse met betrekking tot die betrokkenheid by MIV te kan verwerk. 'n Voorgestelde model kan deur die pastorale berader aangewend word in sy of haar bedieningswerk aan die persoon geaffekteer deur MIV.

Pastoral counselling to people affected by HIV. HIV is a pandemic which influences each and everyone in South Africa, the country in the world with the largest number of people living with HIV. The impact of HIV on the social, economical and micro level is tremendous. The effect of HIV on individual households is immediate, and poverty, sickness, stress, death and loneliness contribute to the devastation caused by this phenomenon.The pastoral counsellor should be equipped with the necessary knowledge to guide and support the person affected by HIV. The counselee must be empowered to handle his or her specific crisis significantly. Perspectives based on Scripture suggest how the Christian believer can manage sickness, suffering and death. The Scripture guides the Christian in times of suffering and conflict to persevere in the hope that God will give deliverance. In the article, it will be shown how the pastoral counsellor must, according to Scripture and as a called shepherd, admonish, educate, support and guide the counselee to accept the ministry of reconciliation, given to her or him by God through Christ his Son. The counselee affected by HIV will have to be empowered by the necessary knowledge in order to care for and support the person affected by HIV and be able to digest and cope with his or her own pain and stress. Pastoral counsellors can make use of the proposed counselling model in order to counsel persons affected by HIV.

\section{Inleiding}

In hierdie artikel word die aandag geskenk aan pastorale berading ${ }^{1}$ aan die persoon geaffekteer ${ }^{2}$ deur MIV. Baie tyd en aandag word bestee aan die begeleiding en versorging van die persoon geïnfekteer deur die MI-virus, maar die persone wat saam met die geïnfekteerde leef en hom of haar moet versorg en bystaan, se trauma en geloofskrisisse word dikwels oor die hoof gesien (Van Dyk 2008:411).

In die formulering van ' $\mathrm{n}$ sinvolle beradingsmodel, wat met die berading aan die persoon geaffekteer deur MIV van hulp kan wees, moet daar gelet word op die Woord van God as kenbron van die basisteorie, in samehang met die hulpbronne uit die verskillende deelwetenskappe.

\section{Probleemstelling}

MIV is een van die mees destruktiewe siektes in die geskiedenis van die mensdom. MIV raak ook nie nie net enkelinge nie, maar elke lid van die samelewing op die een of ander wyse. Die invloed wat hierdie sindroom op die sosiale, ontwikkelings- en ekonomiese gebied gaan uitoefen,

1.Pastorale berading is die praktiese uitvoering van die teologiese wetenskap, toegespits op die bediening van die versoening deur Jesus Christus $(2$ Kor 5:19,20) aan die mens in ' $n$ krisissituasie met die oog op individuele vertroosting, vermaning en opbouing van die persoon op die weg van geloofsgroei (Minnie 2003:3).

2.Persone geaffekteer deur MIV is gesinslede seksmaats, kinders, familie, vriende en kollegas wat op die een of ander wyse betrokke is by die versorging van, of omgaan met die persoon geïnfekteer deur MIV (Minnie 2003:3). 
is geweldig groot. Die effek van MIV op die individuele huishoudings word onmiddellik gevoel (Whiteside \& Sunter 2000:83) waar armoede, siekte, spanning rondom die siekbed, dood en eensaamheid die gesin ruk.

MIV word tans as ' $n$ pandemie in die wêreld geklassifiseer (Van Dyk 2008:7). UNAIDS (2010:21) bereken dat daar in Desember 2009 wêreldwyd 33.3 miljoen mense met die MIvirus geïnfekteer was. In die Sub-Sahara-streek, waaronder Suid-Afrika val, is daar 22.5 miljoen mense wat met MIV geïnfekteer is.

Volgens Dokters Sonder Grense Suid-Afrika was 5.3 miljoen Suid-Afrikaners in 2010 MIV-positief (Ferreira 2011:4). Dit bring volgens UNAIDS (2010:28) mee dat Suid-Afrika die land is waar MIV die hoogste voorkoms het, naamlik onder 17.9\% van die bevolking (Pienaar 2011:9).

Sedert die Suid-Afrikaanse regering se ingryping met die verskaffing van antiretrovirale middels het die aantal MIVverwante sterftes drasties verminder. Daar is bevind dat 1.584 miljoen volwassenes (persone ouer as 15 jaar) en 158000 kinders antiretrovirale middels benodig. Hierdie persone se CD4-telling is laer as 350 selle/ml (NDoH 2010:6), wat daarop dui dat hierdie persone baie siek is en versorging benodig. Dit plaas ' $n$ bykomende las op geaffekteerde persone, want hulle moet langer met die spanning van MIV saamleef.

Volgens Sunderland en Shelp (1987:39) asook Winiarski (2004:136) ervaar persone wat by MIV-positiewe persone betrokke is, dieselfde emosies van skok, hartseer en smart as die pasiënt wat deur die MI-virus geïnfekteer is. Dit is juis op hierdie gebied waar die pastorale berader benodig word. Beraders en terapeute wat in die psigologie, maatskaplike werk en verpleegkunde opgelei is, lewer op hul gebiede belangrike werk, maar op die geestelike gebied is dit die pastorale berader wat die begeleiding moet hanteer. Die mens, wie verbrokkel kan voel deur die aanslag van MIV, is op soek na blywende vertroosting en hoop wat slegs in die vertroostende liefde van God gevind kan word.

Die feit dat daar as gevolg van MIV in 2009 in Suid-Afrika reeds 1.95 miljoen weeskinders was (NDoH 2010:2) en dat daar ander weeskinders was wat hul siek en sterwende ouers versorg, plaas bykomende druk op die pastorale berader om ook hierdie kinders saam met ander geaffekteerdes te begelei om die lewende God se grootheid, almag en liefde in hierdie situasie te ervaar.

Baker (1999:202) vestig die aandag daarop dat persone geaffekteer deur MIV as gevolg van hul betrokkenheid by die vigspasiënt onder groot stres lewe. Die stressors sluit in die geassosieerde stigma $^{3}$ van die siekte, die verantwoordelikheid wat betrokkenheid by die vigspasiënt meebring en die bykomstige las wat die versorging van 'n pasiënt meebring. Stigmatisering veroorsaak dikwels

3.Geassosieerde stigma word gedefinieer as gebeurtenisse wat stigma bewerkstellig teen mense wat werk of geassosieer word met mense wat deur MIV geïnfekteer is (Greeff et al. 2008:313). dat geaffekteerdes vriendskap en familie-ondersteuning moet prysgee as gevolg van die wanpersepsie dat mense deur die MI-virus geïnfekteer kan word wanneer hulle in die omgewing van die geïnfekteerde persoon is; dit het vereensaming tot gevolg (Minnie 2003:110). Die misterie van siekte, lyding, sterwe en dood dra by tot die stres wat die geaffekteerde ervaar (Caliandaro \& Hughes 1998:108). Dit is dus belangrik dat die pastorale berader op hoogte is van die probleme en belewingswêreld van die persoon geaffekteer deur MIV ten einde behoorlike leiding en pastorale hulp aan die beradene te verskaf.

Dit is veral die stelling dat God MIV gebruik om mense vir hulle seksuele losbandigheid te straf (Louw 1994:128) wat ernstige teologiese vrae by die persoon geaffekteer deur MIV laat ontstaan. Dit is hier waar die pastorale berader met geloofskennis die beradene op verantwoordelike wyse na die vertroostende arms van God moet lei. Die pastorale berader moet met insig, empatie, ondersteuning en verkondiging die betrokkenes by die pasiënt met MIV begelei. Die beradene moet met die Woord van God as rigsnoer begelei word om met wysheid probleme en krisissituasies op te los (Collins \& De Vriese 1988:16) sonder om in fundamentalisme of biblisisme te verval.

\section{Die Skrif as kenbron in die pastorale beradingsproses}

Dit is noodsaaklik om kortliks te besin oor die kenbron in die beradingsproses, naamlik die Woord van God self. Pastorale berading aan die persoon geaffekteer deur MIV kan slegs geslaagd wees indien die Woord van God en die God van die Woord hul regmatige plek in die beradingsproses gegun word (Minnie 2003:22).

Die Woord van God het gesag, is betroubaar, genoegsaam en duidelik (vgl. Heyns 1981:29; Peels 1996:57; Nederlandse Geloofsbelydenis Artikel 2-7). Die Bybel het gesag omdat die gesag van God af kom(vgl. 2 Tim 3:16; De Klerk \& Janse Van Rensburg 2005:3). God het die Skrif as onfeilbare en gesagvolle maatstaf vir die geloof en die lewe van die mens verklaar (Adams 1980:167; Heyns 1981:29). Die Skrif is betroubaar omdat God betroubaar is. Deur die Gees van God is die Skrif geïnspireer (2 Pet 1:21; Peels 1996:56; De Klerk \& Janse van Rensburg 2005:3). Die Bybel is deursigtig (Du Plessis 1996:10; vgl. ook Peels 1996:59). Verder is die Bybel ook genoegsaam (vgl. 2 Tim 3:16). Die boodskap van die Bybel, sonder weglating of byvoeging (vgl. Op 22:18-19), is genoegsaam en dus ook noodsaaklik (Wright 2006:180).

\section{Lig op enkele belewingsperspektiewe van MIV-geaffekteerdes}

Vervolgens word enkele perspektiewe gegee op die belewingswêreld van die persoon geaffekteer deur MIV.

\section{Perspektiewe op siekte}

Die tema van hierdie artikel handel nie oor berading aan siek persone per se nie; tog beweeg die beradenes geaffekteer deur 
MIV in die sfeer van siekte en is dit daarom noodsaaklik dat die pastorale berader ook hiervan kennis neem.

Volgens Louw (1983:15; vgl. ook Maartens 2006a:155) is siekte ' $n$ verhoudingsaangeleentheid. Dit raak die mens in sy of haar diepste verhouding, naamlik sy of haar verhouding tot God. Dit is daarom belangrik om vas te stel watter Skrifperspektiewe ten opsigte van siekte ondersoek kan word.

In die $\mathrm{Ou}$ Testament moet siekte binne die kulturele en godsdienstige konteks van die volk Israel verstaan word. Israel, die verbondsvolk, het 'n groot deel van die dag afgestaan aan gemeenskap met God. 'n Gebrek aan lojaliteit teenoor God kon die seën in die toorn van God omskakel. Die verwydering uit die verbondsgemeenskap het vir die Israeliet dieselfde as die dood beteken (Louw 1994:30).

Volgens die Ou Testament is daar dus 'n verband tussen sonde en siekte. Hierdie verband moet egter as redegewend gesien word. Hierdie redegewende verband tussen sonde en siekte moet nie gesien word asof persoonlike sonde altyd die oorsaak van siekte is nie, maar dat siekte 'n gevolg van persoonlike sonde kan wees. In die Ou Testament was die bedoeling om die siek persoon weer na die verbondsgemeenskap met God terug te bring, soos dit byvoorbeeld in Ps 41:4 hanteer word (Louw 1994:31).

Die Nuwe Testament sluit aan by die gedagte van sondesiekte (Joh 5:14), maar lê ook besondere aksent op die invloed van demoniese magte (Luk 13:11; Op 16:2; Craffert 1999:14). Verder sluit die Nuwe Testament ook aan by die gedagte van siekte as deel van die algemene swakheid waaraan die menslike bestaan onderworpe is (vgl. byvoorbeeld Matt 10:8; Joh 4:46; Hand 9:37; Craffert 1999:1).

Volgens Markus 2:7-9 word sonde en/of verlossing en siekte baie nou in verband met mekaar gebring. Jesus vergewe die siek man sy sondes op grond van sy geloof in God (vgl. Louw 1983:17). Hendriksen (1981:89) wys daarop dat Jesus nooit net sondes vergewe het nie. Daar gebeur altyd iets saam met die vergifnis. Hier herstel hy die siek man sodat hy weer kan loop, wat ' $n$ aanduiding is van sy liefde vir die mens.

Dit is verder uit die Skrif duidelik dat daar aan sekere siektes 'n stigma gekleef het, byvoorbeeld melaatsheid wat die sieke genoop het om buite die stad, as onreine, te gaan woon (2 Kon 7:3). Jesus Christus toon medelye met dié siekes deur met hulle om te gaan en selfs aan hulle te raak (Matt 8:3). Deur aan die onreine te raak, betoon Hy sy empatie. Deur aan die onreine te sê: 'Word gesond!', stel nie net dat heling moet plaasvind nie, maar ook reiniging (Osborne 2010:284). Hiermee wys Hy dat, al is die sieke deur mense verlaat, God nooit die sieke vergeet of verlaat nie.

\section{Perspektiewe op lyding}

Die sin van lyding is dikwels die knellendste vraag wat deur die beradene aan die berader gerig word. Wanneer die sin van lyding deur die beradene aanvaar word, word krisisse gemakliker hanteer. Dit is dus uiters belangrik dat die pastorale berader hierdie aspek baie duidelik in die beradingsproses aanspreek.

\section{Die oorsprong van lyding}

König (2001:211) stel dit baie duidelik dat die oorsprong van lyding nie by God te vind is nie, maar dat mense die oorsaak van hul eie lyding is. God hef ook nie onmiddellik die lyding op nie, maar is tog in die nood en ellende teenwoordig om die mens te troos.

Die oorsprong van lyding soos dit gevind word by die sondeval, word op die rekening van die mens geplaas (Rm 5:12; 1 Tim 2:13, 14). God spreek na die sondeval 'n drieledige vloek uit wat al die menslike lyding saamvat (Gn 3:14-19; vgl. De Klerk 1985:53; Helberg 1994:464):

- Eerstens is die mens vir sy broodwinning van die vervloekte aarde afhanklik: Hieruit volg alle bestaanslyding.

- Tweedens is aan die vrou opgelê dat sy in smart kinders sal baar en beheers sal word na die begeerte na die man; vervreemding tussen man en vrou tree na die sondeval in: Hieruit volg alle verhoudingslyding tussen geslagte en in die gesins- en verhoudingslewe.

- Derdens is die vloek van die dood en verganklikheid oor die mens uitgespreek: Hieruit volg alle lyding van siekte en dood.

Smit (1982:48) maak die belangrike stelling dat God nie wil hê dat die mens pyn en lyding ervaar nie. Die Skrif laat ons God ken as die Een wat ten volle by die mens se smart en lyding betrokke is. Hyself is benoud as sy volk benoudheid ervaar (Jer 31:20). God is nie 'n wrede, apatiese en onbetrokke God nie, maar gee selfs sy Seun uit medelydende liefde vir sy kinders (De Kock 2007:63).

Vir die ongelowige daarenteen is lyding wreed, onwerklik en verskriklik. Lyding is gelyk aan onmenslikheid. Lyding is ' $n$ degradering vir die menslikheid van die mens (Louw 2006:43).

Dit is belangrik om daarop te let dat God wel in beheer is, ook in elke lydingsituasie (Smit 1982:49). Elke haar van die kind van God is getel (Matt 10:30); niks kan die gelowige uit die hand van die Vader ruk of hulle skei van die liefde van Jesus Christus nie (Rm 8:39; vgl. Duvenage 2005:46).

In aansluiting hierby verkondig die Skrif dat God lyding positief kan buig sodat beproewings as louter vreugde gesien kan word. Die beproewings kan wel versoekings word, maar eers deur die verkeerde menslike reaksie op die beproewings. Vir die Psalmdigter was dit goed as God toelaat dat hy verdruk word (vgl. Ps 73). Ook die gemeente in Rome roem saam met Paulus in die verdrukking, want dit bewerk lankmoedigheid en hoop (Rm 8:18; De Kock 2007:81). Die gemeente het die versekering dat alles ten goede meewerk vir hulle wat God liefhet (Rm 8:37; Smit 1982:49).

\section{Die doel van lyding}

Die wete dat enige lyding wat die gelowige ervaar, deel van God se algehele plan is, bring vertroosting. Een van die redes 
waarom God lyding toelaat, is om die gelowige se geloof te toets (vgl. Job 23:10; MacArthur 2000:21). Louw (1997:461) dui ook aan dat die wil van God in lyding nie soseer die lyding as sodanig is nie, maar dit wat in die hart van die lydende persoon kan gebeur (vgl. 1 Pet 2:19).

Petrus gebruik in 1 Petrus 4:12 die woord $\pi v \rho \omega \sigma \varepsilon 1$ wat in die Nuwe Afrikaanse Vertaling met vuurproef vertaal is. Brown (1979:656) verklaar dat lyding 'n louteringsproses is. Soos wat 'n edelmetaal deur vuur tot volmaaktheid gelouter word, so word die gelowige deur lyding van onreinhede gesuiwer. Louw en Nida (1988:690) verklaar dat die intensiteit waarmee die gelowige die lyding ervaar, geweldig sal wees. Lyding is 'n uiters pynlike ervaring (Groenewald 1977:82).

\section{Houding ten opsigte van lyding}

Die apostel Petrus beklemtoon in sy eerste brief (1 Pet 4:12-14) die lydingstema en noem twee elemente wat ' $n$ positiewe houding in reaksie op lyding uitmaak. Die eerste houdingskomponent wat die gelowige deur moeilike tye sal help, is om nie verbaas $(\xi \varepsilon v i \zeta \varepsilon \sigma \theta \varepsilon)$ te wees wanneer teëspoed jou tref nie. Die gelowige moet weet dat teëspoed en lyding onvermydelik is (MacArthur 2000:94).

'n Tweede houdingselement is dat die gelowige haar in die lyding moet verbly ( $\chi \alpha 1 \rho \varepsilon \tau \varepsilon)$. Hierdie positiewe houding teenoor lyding is dwarsdeur die Skrif teenwoordig en kan moeilik geïgnoreer word. Die soewereine God het ' $n$ doel met die mens se lyding en daarom maak dit sin dat die gelowige hom daarin verheug. Selfs die ergste lyding is die gelowige tot voordeel (vgl. Rom 8:28; MacArthur 2000:96).

1 Petrus 4:15-19 wys ook op twee verdere elemente wat vir die regte houding jeens lyding noodsaaklik is. Petrus stel hier die derde eienskap wat nodig is om lyding te hanteer, naamlik om dit te beoordeel. Daar moet nie nagelaat word om God om die nodige onderskeidingsvermoë te vra om die doel van lyding te begryp nie (MacArthur 2000:99).

Die laaste element wat in die Christen se houding jeens lyding teenwoordig moet wees, is om homself of haarself aan God toe te vertrou (1 Pet 4:19). Die woord toevertrou ( $\pi \alpha \rho \alpha \tau \theta \theta \varepsilon \sigma \theta \omega \sigma \alpha \nu)$ beteken om iets of iemand met vertroue aan die sorg van iemand anders oor te gee. Petrus doen 'n beroep op alle gelowiges wat ly om hulle siel (lewe) aan die sorg van die getroue Skepper oor te gee (vgl. ook Rom 12:1). God het die mens geskep en daarom kan die gelowige ten volle op Hom vertrou (MacArthur 2000:102).

\section{Perspektiewe op sterwe en dood}

Dit is belangrik dat die berader kennis dra van die verskynsel van sterwe en dood in die begeleiding van die beradene geaffekteer deur MIV. Die beradene wat die sterwende vigspasiënt versorg en bystaan, vra dikwels wat die dood inhou en moet soms self sterwensbegeleiding aan die sterwende bied (WCC 1997:89). Dit is daarom noodsaaklik dat sterwe en dood eerstens vanuit die Skrif belig word, maar dit moet ook vanuit die ander deelwetenskappe verklaar word.
Aan die einde van elke individu se lewe staan die dood. Die dood is onvermydelik. Van de Brake et al. (1974:7) onderskei tussen doodgaan en sterwe. Doodgaan is passief; dit is die einde van 'n lewe, terwyl sterwe 'n aktiewe gebeurtenis is. Die mens sterf elkeen op 'n eie, persoonlike wyse (vgl. Venter 1979:57). Corr, Nabe en Corr (2003:127) wys daarop dat sterwende mense steeds lewende wesens is. Sterwe is ' $n$ spesiale tydperk in 'n mens se lewe en dood is die gevolg van sterwe. In die lig hiervan is dit duidelik dat die sterwende steeds ' $n$ wye verskeidenheid behoeftes het, naamlik planne, blydskap, hartseer, vrese en hoop (vgl. Van Dyk 2008:325).

Indien die sterwensproses ' $n$ tyd lank aanhou voordat die dood intree, soos by die meeste vigspasiënte, kan dit ' $n$ invloed uitoefen op hoe naasbestaandes na die tyd die dood aanvaar (Cleiren 1993:5; Van Dyk 2008:325). Die persoon geaffekteer deur MIV word as't ware op die rouproses voorberei, maar kan ook as gevolg van die oorlading van smart, stres, uitbranding en 'n gevoel van magteloosheid verlengde rousmart ervaar (Van Dyk 2008:412).

Uit die Skrif is dit duidelik dat die dood vir die gelowige, wat tydens sy of haar aardse lewe God gedien en geëer het, 'n tydperk van rus en geluksaligheid is, 'n tydperk waar daar geen swaarkry, pyn of ongemak is nie. Vir die ongelowige is lyding egter verskriklik, en hierdie pyn kan deur niemand verlig word nie (vgl. Luk 16:19-31; Geldenhuys 1975:425; Hendriksen 1984:785).

Vir die Christengelowige is die dood slegs ' $n$ deurgang na die ewige lewe. Die siel is onverganklik en die liggaam gaan weer opgewek word. Tog het hierdie siening vervaag en word daar volgens Moscrop (1995:6; vgl. ook Van Dyk 2008:325) drie standpunte gehuldig oor wat met die mens gebeur as sy of hy sterwe:

- Sekere geloofsgroepe glo onwrikbaar in die lewe na die dood, hoewel die wyse waarop daar gelewe gaan word, nie duidelik is nie.

- Sommige mense handhaaf ' $n$ neutrale siening, maar wil ook nie die moontlikheid van ' $n$ lewe hierna afskryf nie. Christene wat hierdie siening handhaaf en tot sterwe kom, soek hulp om die saak te begryp.

- Laastens is daar diegene wat baie duidelik stel dat die dood die einde van lewe beteken. Al wat oorbly, is herinneringe aan die dooie mens.

\section{Perspektiewe op hoop}

Lyding, siekte en sterwe roep telkens die een of ander vorm van hoop op, of dit nou hoop op beterskap en herstel is, hoop op spanningsverligting of hoop op troos. Sonder hoop voel die mens nutteloos. Die persoon geaffekteer deur MIV moet verseker weet dat daar vir hom of haar hoop is ten spyte van al die spanning en negatiewe gevolge wat aan MIV verbonde is.

Hoop aan die gelowige beteken volgens Louw (1997:532) dat dit in God se trou aan sy beloftes gefundeer is. Die hoop word gedra en gestimuleer deur die toesegging van 
die verbondsbeloftes en die inhoud van die beloftes is die heil van die mens, die waarborg van ' $\mathrm{n}$ daaglikse sinvolle lewe, asook die uiteindelike ewige lewe (Maartens 2006b:20). Lester (1995:65) stel dat die grondslag van hoop in die Skrif in die persoon van God, die Skepper en Verlosser van die heelal, gewortel is.

Christelike hoop kan nie van die geloof geskei word nie. Die hoop bly ' $n$ funksie van die geloof, want die geloof gee substansie aan die hoop (Louw 2006:139). Die inhoud van die Christelike hoop is die heil in Christus as daad van die Drieenige God. Die Christelike hoop is ooreenkomstig Christus se opstanding opstandingshoop, deur die Heilige Gees se troosvolle werking is dit ' $n$ blywende lewende hoop en volgens die Verbondsgod se trou 'n geborge hoop (Egan 2010:295). Die Christen se uiteindelike hoop is op die ewige lewe gerig (Tit 3:7).

Swindoll (1999) stel dat hoop 'n wonderlike geskenk van God is, ' $n$ bron van krag en moed ten spyte van die wreedste beproewings van die lewe. Daar is altyd hoop, ongeag die situasie:

- Wanneer ellende die mens die donkerte indryf, is hoop die lig aan die einde van die tonnel.

- Wanneer die mens oorwerk en uitgeput is, gee hoop nuwe krag.

- Wanneer die mens moedeloos word, gee hoop nuwe optimisme.

- Wanneer die mens in die versoeking kom om tou op te gooi, laat hoop haar of hom voortgaan.

- Wanneer die mens die pad byster raak en nie meer weet waar sy of haar bestemming is nie, versag hoop die paniek wat hom of haar wil oorval.

- Wanneer die mens met ' $n$ akute siekte of voortslepende ongesteldheid worstel, help hoop om bo die pyn uit te styg.

- Wanneer die mens die ergste vrees, herinner hoop dat God steeds in beheer is.

- Wanneer die mens die gevolge van verkeerde besluite moet verduur, vuur hoop haar of hom aan om weer te begin.

- Wanneer die mens sy of haar werk verloor, sê hoop dat daar nog steeds ' $n$ toekoms is.

- Wanneer die mens gedwing word om te wag, gee hoop die geduld om te vertrou dat dinge sal regkom.

- Wanneer die mens verwerp en verlate voel, herinner hoop haar of hom daaraan dat sy of hy nie alleen is nie.

- Wanneer die mens 'n geliefde vir die laaste keer groet, help hoop op die lewe hierná om die smart te verwerk. (bl. 11)

\section{MIV in die lewe van die geaffekteerde persoon}

Ten einde berading aan persone geaffekteer deur MIV behoorlik te kan behartig, is dit nie net noodsaaklik dat die berader kennis neem van hoe die beradene die krisis ervaar nie, maar moet sy of hy ook toegerus wees met die nodige kennis van MIV en MIV-verwante siektes en die invloed daarvan op die individu, familie, gemeenskap en wyer omgewing. Kennis bemagtig die berader om die geaffekteerde empaties te kan bystaan en begelei. Verskeie bronne is in die literatuur oor MIV beskikbaar. In die lig hiervan sal daar nie hier by die werking en die verloop van die MI-virus stilgestaan word nie. ${ }^{4}$

\section{Die invloed van MIV-infeksie op die geaffekteerde persoon}

\section{Stigmatisering}

Diskriminasie teen persone met MIV is algemeen en kan vir sowel die geïnfekteerde pasiënt as die geaffekteerde skadelik wees. Die bekendmaking van 'n persoon se MIV-status lei dikwels tot die verlies van werk, behuising, gesondheidsorg, vriendskap en familie-ondersteuning (Patania 1998:247; Greeff et al. 2008:313).

Die gevolge van stigmatisering kan volgens Leary en Schreindorfer (1998) kortliks soos volg gestel word:

- die verlies van interpersoonlike verhoudings;

- psigologiese gevolge, wat insluit negatiewe emosies, depressie, angs, vyandigheid en eensaamheid;

- versnelde agteruitgang in die gesondheid van die geïnfekteerde pasiënt; en

- organisasies is huiwerig om betrokke te raak by die bekamping van MIV vanweë die negatiewe lewenswyses wat tot die infeksie aanleiding gee. (bl. 21)

\section{Veranderings in die gesinstruktuur}

Die gesinstruktuur word dikwels verander wanneer een van die gesinslede met MIV gediagnoseer word of te sterwe kom. 'n Ouer of kind moet dikwels as gevolg van die afsterwe van 'n gesinslid rolle in die gesin vertolk wat normaalweg nie as syne gereken word nie, byvoorbeeld ' $n$ kind wat die rol van versorger moet inneem as een of albei ouers gesterf het (Van Dyk 2008:347).

\section{Psigososiale gevoelens van die geaffekteerde persoon}

Die geaffekteerde persoon ervaar volgens Kgosikwena (2001:208) en Van Dyk (2008:270-271) dieselfde psigososiale gevoelens as die MIV-positiewe persoon, naamlik depressie, eensaamheid, vrees, onsekerheid, angstigheid, aggressie en emosionele verslaenheid, asook hoop.

- Vrees - Die geaffekteerde persoon is bevrees dat hyself of syself, as gevolg van sy of haar verhouding met die persoon, as MIV-positief gediagnoseer kan word.

- Aggressie - Die geaffekteerde persoon is dikwels woedend vir die geïnfekteerde persoon oor die situasie waarin hy of sy hulle geplaas het.

- Smart - Die geaffekteerde persoon begin met 'n rousmartproses, in afwagting op die verlies van die geïnfekteerde persoon asook die onsekerhede wat voorlê.

- Gevoel van hulpeloosheid - Die geaffekteerde persoon voel onbeholpe, onopgelei en magteloos om die nuwe uitdagings wat die infeksie meebring, te hanteer.

- Skok-Die bewuswording van 'n geliefde se MIV-positiewe status is altyd 'n skokkende gewaarwording.

4.Van Dyk (2008); Winiarski (2004). 
- Depressie-Depressie word ervaar omdat die geaffekteerde persoon bewus word dat hy of sy so baie verloor: 'n geliefde, finansiële middele, asook verliese geassosieer met die las om die geïnfekteerde persoon te versorg.

\section{Ondersteuning vir die geaffekteerde persoon}

Daar is min twyfel daaroor dat persone geaffekteer deur MIV van sosiale ondersteuning afhanklik is. Ondersteuning is nodig om die eiewaarde te herstel, om die sin van die siekte en lyding te verwerk, asook om te help om weer beheer oor die lewe te verkry (Frey et al. 1998:129).

Die pastorale berader het 'n groot ondersteuningstaak met betrekking tot die berading en begeleiding van die persoon geaffekteer deur MIV.

\section{Perspektiewe op berading}

Die term pastorale berading word verkies. Pastorale berading, soos wat dit in hierdie artikel ter sprake kom, gebruik die Bybel as rigtingwyser in die beradingsproses. Pastorale berading sluit ook begrippe soos Bybelse berading, Bybelgefundeerde berading, bediening van die versoening en pastorale versorging in (Collins 1988:16; Louw 1997:27).

Pastorale berading het die mens as objek. Die lewende, soewereine God is die subjek van pastorale berading (MacArthur \& Mack 1994:57), dié God wat Hom deur die skepping en onderhouding daarvan aan ons openbaar, maar Hom nog duideliker en volkome bekend maak deur sy heilige en goddelike Woord, soveel as wat ons nodig het in hierdie lewe, tot sy eer en saligheid (Nederlandse Geloofsbelydenis Artikel 2). Die pastorale berader wat deur omgang met die Skrif die lewende God beter leer ken en na die eise van sy Woord leef, gebruik hierdie geloofskennis om die objek van die berading, naamlik die mens, te begelei om oplossings vir krisisse, trauma, hartseer, smart en pyn te vind.

Collins (1993) stel dat pastorale berading verskil van ander vorme van berading deurdat die berader se aanslag, haar of sy tegnieke en einddoel met die berading van dié van ander beraders verskil. Die pastorale berader se einddoel is die begeleiding van die beradene na die wagtende, liefdevolle God wat vertroos en versorg. Die pastorale berader behoort aan die volgende kriteria te voldoen:

- 'n toegewyde dienaar van Jesus Christus, gelei deur die Heilige Gees;

- 'n dienaar wat sy of haar Godgegewe gawes, vaardighede, opleiding, kennis en insig tot eer van God gebruik; en

- 'n dienaar wat ander help om na 'n persoonlike geloofsverhouding, interpersoonlike vaardigheid, geestelike stabiliteit en geestelike volwassenheid te beweeg of dit te verdiep. (bl. 21)

Die opgeleide berader, geskool in die psigososiale wetenskappe en/of die teologie, is slegs die instrument in die hand van die almagtige God, wat deur sy Heilige Gees in mense se lewens ingryp en verandering in verslae harte teweegbring (MacArthur \& Mack 1994:57; Louw 1997:1). Bor et al. (2000:14) veronderstel dat alle berading psigoterapie in die beradingsproses insluit. Hierdie stelling is nie waar nie, aangesien pastorale berading per definisie riglyne vanuit die Skrif neem om genesing te bewerkstellig. Daar mag volgens Louw (1997:298) wel raakvlakke tussen psigoterapie en pastorale berading wees, maar pastorale berading spits ditself daarop toe om die beradene openbaringsmatig vanuit 'n skeppings- en herskeppingsmatige perspektief te benader. Die pastorale berading soek na die hoogste mate van geloofsrealisering en versoening van die beradene.

Bor et al. (2000) stel die volgende as doelwitte vir die berading waarby pastorale berading aansluiting vind:

- 'n Goeie verhouding met die beradene is noodsaaklik sonder om haar of hom onder ' $n$ wanindruk oor die uitslag van die berading te bring.

- Ruim alle wanindrukke uit die weg (byvoorbeeld dat die verhouding op lewenslange vriendskap gerig is).

- Vestig deur dialoog 'n verhouding met die beradene.

- Bly tydens die beradingsessie gefokus en hanteer moeilike en uitdagende situasies dadelik.

- Verskaf die nodige inligting wat relevant is vir die beradene.

- Definieer die probleem, ondersoek die gevolge en oorweeg die moontlike metodes wat aangewend kan word om die saak aan te pak.

- Moedig die beradene aan om oor belangrike sake te praat.

- Oorweeg moontlike opsies waar familie, vriende of kollegas in ondersteuningsgroepe die beradene kan bystaan.

- Bepaal die ernstigheid van die beradene se besorgdhede en pak dit aan.

- Help die beradene om opsies te oorweeg en ingeligte besluite te neem sodat sy of haar situasie kan verbeter. (bl. 62)

Berading word gedoen vanuit bepaalde beradingsriglyne waarmee die berader haar of hom kan vereenselwig en waarmee sy of hy gemaklik voel.

\section{Beradingsriglyne}

In die opstel van Skrifgefundeerde beradingsriglyne vir die gebruik by persone geaffekteer deur MIV is dit nodig om sekere sentrale uitgangspunte in ag te neem, naamlik 'n pastorale grondhouding, die spiritualiteit van die berader en beradene, die beradingsgesprek, asook Skrifgebruik en gebed (Minnie 2003:241-242).

'n Pastorale grondhouding moet verstaan word as die gesindheid, mentaliteit, karakter, medemenslikheid en kommunikatiewe sensitiwiteit wat die beradingsoptrede ten grondslag lê. Die komponente van die pastorale grondhouding kan omskryf word as empatie, aanvaarding, wederkerigheid en vryheid:

- Empatie word geïmplementeer deur die verskillende akte van luister, naamlik aanvaardende, observerende, vraende en reflekterende luister. Die verskillende vlakke van luister is: 
- Op kognitiewe vlak word geluister na die direkte inhoud van wat gesê word.

- Op emosionele vlak word geluister na die gevoelstone en gevoelswaarde van woorde.

- Op eksistensiële vlak word geluister na die diepste waardes van die beradene (verhouding tot God, eggenoot, kinders).

- Op stiltevlak word die stiltes in die gesprek geïnterpreteer (De Klerk 1985:219-220; Venter 1996:119).

- Aanvaarding as komponent van die pastorale grondhouding beteken om die beradene geaffekteer deur MIV te aanvaar soos hy of sy is, omdat God sowel die gelowige berader as beradene onvoorwaardelik aanvaar het soos hulle is (vgl. Joh 13:34-35; Venter 1972:153).

- Wederkerigheid beteken die meegaan van sowel die berader as beradene op die weg van insig in ' $n$ betrokke saak of proses. Dit hou in dat die beradene voortdurend in pas met die gevoelens en houding van die beradene moet bly (Venter 1972:154).

- Met vryheid word geïmpliseer dat die beradene haar of hom vry moet voel om al haar of sy gevoelens en houdinge tot uitdrukking te bring en geen houding té aggressief en geen gevoel té skandelik te vind om na vore te bring nie (Venter 1972:156).

Die oefening in spiritualiteit is vir die berader self onmisbaar. Bestudering van die Skrif, gebed, lofprysing en skuldbelydenis en meditasie om met God gemeenskap te beoefen en aan God lof toebring is aspekte waarsonder die herderlike bediening ondenkbaar is (Velema 1990:160; vgl. Collins 2005:32-334).

Die spiritualiteit van die berader of pastor hou volgens Venter (1999:200; ook Velema 1994:43) die volgende in:

- Ware spiritualiteit beteken dat die pastor eers begenadigde kind van God is en dan pastor.

- Groei in spiritualiteit hang nou saam met die pastor se omgang met die Woord.

- As 'n pastor in sy of haar spiritualiteit stagneer, kan hy of sy nie die beradenes toerus nie.

- 'n Wesensdeel van die pastor se spiritualiteit is gereelde selfondersoek.

In die beradingsproses moet die berader daarop let dat geestelike verdieping in die beradene se lewe, wat deur Christus se verdienste en die werk van die Heilige Gees vernuwe is en waarin spiritualiteit tot uiting kom, gewoonlik prosesmatig is (Pieterse 1989:52). Die beradene moet dus geleentheid gegun word om haar of sy krisis in die lig van haar of sy nuut-verworwe kennis en verhouding met God te verwerk.

Uiters belangrik in die gebruik van beradingsriglyne vir berading aan die persoon geaffekteer deur MIV is die verkondiging dat God, ten spyte van die siekte, lyding en hoop-loosheid, nog steeds in beheer is. Tog gee God aan die mens vryheid van optrede. Die vryheid bring dikwels mee dat die mens geneig is om die verhouding met God te verwerp. Die erkenning van die mens dat hy of sy sonde doen en dit wil regstel, kan bekering genoem word. God vergewe die mens se sonde deur Jesus Christus (Hand 2:38). In die lig hiervan is dit ook belangrik dat die mens ander wat teen haar of hom oortree, vergewe (Matt 6:14-15).

Vergifnis veroorsaak dat 'n gebroke verhouding weer herstel word. Die situasies wat tot die infektering met die MI-virus lei, kan veroorsaak dat verhoudings seerkry en dat dit ' $n$ lang tyd neem om hierdie gebroke verhoudings weer te herstel. Betrokkenes by die MIV-situasie kan mekaar oor onsensitiewe optrede, owerspel of losbandigheid verwyt. Ware vergifnis bring weer heelheid in die verhouding (WCC 1997:26; Maartens 2006a:171).

In die bediening van die persoon geaffekteer deur MIV moet die pastorale berader in die beradingsproses van die belewing van verskillende krisisse deur die persoon geaffekteer deur MIV bewus wees en hom of haar begelei om vanuit die geloof die krisis met hoop te benader.

Louw (1985:105-106) wys daarop dat wie die krisis vanuit die geloof en die hoop benader, dit as ' $n$ geleentheid sal beskou om:

- Meer van God se liefde, genade en barmhartigheid te ontdek.

- In die wete dat God in sy verbondstrou in beheer is, te kan rekening hou met die misterie en onverklaarbaarheid van lyding.

- Te ervaar dat mensgemaakte krukke wegval sodat die mens net aan God vashou met die wete: God hou die gelowige in elk geval vas.

- Te beleef hoedat lyding die kwantiteit van lewe inkort, maar die kwaliteit daarvan verdiep.

- Te groei in die wete dat lyding 'n louteringsproses is en 'n opvoedingsmaatreël binne die vermanende greep van ' $n$ liefdevolle Vader.

- In gemeenskap met die lyding van Christus geestelik groei.

- Meer diensbaar te wees vir God en medemens.

In die lig van bogenoemde word die volgende beradingsriglyne vir die berading aan die persoon geaffekteer deur MIV voorgestel. Hierdie riglyne het God Drie-enig as die fokus van die beradingsproses. Die beradene in 'n gebroke dimensie, deur die krisisse en trauma veroorsaak deur die saamleef met en versorging van die pasiënt met MIV-verwante siektes, word begelei met riglyne uit die Woord van God, onder leiding van die Heilige Gees, met inagneming van hulpmodelle gestel deur ander deelwetenskappe, na 'n nuwe dimensie waar die mens sy of haar afhanklikheid en hoop op God stel en daaruit lewe.

Die riglyne sluit volgens Minnie (2003:258) verskillende fases in wat nodig is vir sinvolle pastorale berading, naamlik verhoudingsbou, ontleding van inligting, onderhoudvoering (sluit in die luister na die verhaal van die beradene en die vermaning en bemoediging waar nodig), ontmoeting met God, onderwysing en ondersteuning. Hierdie fases mag oorvleuel en word slegs as ' $n$ riglyn vir die beradingsproses gebruik. 


\section{Slot}

In die lig van die Woord kan die pastorale berader met die nodige pastorale beradingsriglyne die persoon geaffekteer deur MIV begelei, met inagneming van sy of haar belewing van siekte, lyding en dood, deur sy of haar krisisse soos depressie, stres, rousmart en verwarring, tot 'n sinvolle en hoopvolle hantering van die situasie. Die pastorale beradingsproses is op die heil van die beradene en die eer van God gerig.

\section{Erkenning \\ Mededingende belange}

Die outeurs verklaar dat hulle geen finansiële of persoonlike verbintenis het met enige party wat hulle nadelig of voordelig kon beïnvloed in die skryf van hierdie artikel nie.

\section{Outeurbydraes}

Die outeurs F.G.M. (Noordwes-Universiteit) en G.A.L. (Noordwes-Universiteit) het gelyk bygedrae tot die navorsing en skryf van hierdie artikel.

\section{Literatuurverwysings}

Adams, J.E., 1980, Shepherding God's flock. A preacher's handbook on pastoral ministry, counseling and leadership, Presbyterian and Reformed, Phillipsburg.

Baker, S., 1999, 'Home care: Addressing the needs of people living with HIV/AIDS and their caregivers', The Nursing Clinics of America 34(1), 202-210.

Bor, R., Miller, R., Latz, M. \& Salt, H., 2000, Counselling in health care settings, Cassel, London.

Brown. C., (ed.), 1979, The New International Dictionary of New Testament Theology, vol. 1, Zondervan Publishing House, Zondervan.

Caliandaro, G. \& Hughes, C., 1998, 'The experience of being a grandmother who is the primary caregiver for her HIV-positive grandchild', Nursing Research 4(2), 108

Cleiren, M.P.H.D., 1993, Bereavement and adaptation: A comparative study on the aftermath of death, Hemisphere Publishing Corporation, Washington.

Collins G.R., 1988, Christian Counseling. A Comprehensive Guide, Word Publishing, Dallas.

Collins, G.R., 1993, The Biblical basis of Christian Counseling for people helpers, Navpress, Colorado Springs.

Collins, G.R., 2005, Die A tot Z van berading, Struik Christelike Boeke, Kaapstad.

Collins, G.R. \& De Vriese, J., 1988, Doeltreffende pastorale counseling. De herderlijke taak van de plaatselijke gemeente, Gideon, Hoornaar.

Corr, C.A., Nabe, C.M. \& Corr, D.M., 2003, Death and dying, life and living, Wadsworth, Belmont.

Craffert, P.F., 1999, IIIness, health and healing in the New Testament, Biblia Publishers, Pretoria.

De Klerk, B.J. \& Janse van Rensburg, F., 2005, Preekgeboorte, Potchefstroom Teologiese Publikasies, Potchefstroom.

De Klerk, W.J., 1985, Rousmart. Die pastorale sorg oor bedroefdes na die oorlye van 'n dierbare, Boekhandel De Jong (Edms) Bpk, Johannesburg.

De Kock, D.J., 2007, 'Pastorale begeleiding van gesinne met betrekking tot die sin van lyding by gestremdheid', PhD proefskrif, Noordwes-Universiteit, Potchefstroom.

Du Plessis, M.J., 1996, Ek glo en werk, M.J. du Plessis, Kempton Park.

Duvenage, B., 2005, 'Worstelinge oor die waaroms in die lewe', Die Bybelskool van Centurion, Lyttleton.

Egan, J., 2010, From misery to hope, Peter Lange, Bern.

Ferreira, L. 2011, 'Ramp voorspel oor min geld vir MIV-middels', Beeld, 29 November, p. 4.

Frey, L.R., Query, J.L., Flint, L.J. \& Adelman, M.B., 1998, 'Living together with AIDS', in V.J.' Derlega \& A.P. Barbee (eds.), HIV \& Social interaction, pp. 129-146, Sage, London.

Geldenhuys, N., 1975, Commentary on the Gospel of Luke. The New Internationa Commentary on the New Testament, Eerdmans Publishing Company, Grand Rapids.

Greeff, M., Phetlhu, R., Makoae, L.N., Dlamini, P.S., Holzemer, W.L., Naidoo, et al., 2008, 'Disclosure of HIV status. Experiences and perceptions of persons living with HIV/AIDS and nurses involved in their care in Africa', Qualitative Health Research 18(3), 311-324.

Groenewald, E.P., 1977, Die Briewe van Petrus. Die Brief van Judas, NG Kerk-Uitgewers, Kaapstad.
Helberg, J.L., 1994, 'Ou-Testamentiese perspektiewe op lyding', In die Skriflig 21(3), 463-467.

Hendriksen, W., 1981, The Gospel of Mark. New Testament Commentary, The Banner of Truth Trust, Edinburgh.

Hendriksen, W., 1984, The Gospel of Luke. New Testament Commentary, The Banner of Truth Trust, Edinburgh.

Heyns, J.A., 1981, Dogmatiek, NG Kerkboekhandel Transvaal, Pretoria.

Kgosikwena, K.B., 2001, 'Pastoral care and the dying process of people living with HIV/ AIDS', Missionalia 29(2), 200-219.

König, A., 2001, 'Fokus op die 300 geloofsvrae wat mense die meeste vra', Lux Verbi, Wellington.

Leary, M.R. \& Schreindorfer, L.S., 1998, 'The stigmatization of HIV and AIDS. Rubbing salt in the wounds', in V.J. Derlega \& A.P. Barbee (eds.), HIV and social interaction, salt in the wounds', in V.J.
pp. 12-29, Sage, London.

Lester, A.D., 1995, Hope in Pastoral Care and Counseling, Westminster John Knox Press, Louisville.

Louw, D.J., 1983, Siekepastoraat. Siekwees as krisis en geleentheid, NG Kerkboekhandel, Pretoria.

Louw, D.J., 1985, 'Sin in lyding', Lux Verbi, Kaapstad.

Louw, D.J., 1994, Illness as crisis and challenge. Guidelines for pastoral care, Orion Publishers, Halfway House.

Louw, D.J., 1997, Pastoraat as vertolking en ontmoeting. Teologiese ontwerp vir ' $n$ basisteorie, antropologie, metode en terapie, Lux Verbi, Kaapstad.

Louw, D.J., 2006, Hoekom? Hoekom nie? Waar is God wanneer ek ly? En waarom ly $e k$ ?, Lux Verbi BM, Wellington.

Louw, J.P. \& Nida, E.A., (eds.), 1988, Greek-English Lexicon of the New Testament based on Semantic Domains, vol. 1 \& 2, United Bible Societies, New York.

Maartens, M. (red.), 2006a, Deur Trauma - Boek 3, Lapa Uitgewers, Pretoria.

Maartens, M. (red.), 2006b, Deur Trauma - Boek 4, Lapa Uitgewers, Pretoria.

MacArthur, J.F., 2000, Waarom laat God lyding toe?, Christelike Uitgewersmaatskappy, Vereeniging.

MacArthur, J.F. \& Mack, W.A., 1994, Introduction to Biblical counseling. A basic guide to the principles and practice of counselling, Word Publishing, Dallas.

Minnie, F.G., 2003, 'Bybelse berading aan die persoon geaffekteer deur MIV/VIGS', PhD-proefskrif, Fakulteit Teologie, PU vir CHO, Pochefstroom.

Moscrop, J., 1995, 'Looking at death and dying', in J. Robbins \& J. Moscrop (eds.) Caring for the dying patient and the family, pp. 1-7, Chapman \& Hall, London.

$\mathrm{NDoH}$, South Africa (Republic), 2010, 'National Department of Health. National Antenatal Sentinel HIV and Syphilis Prevalence Survey in South Africa', 2009, Antenatal
Pretoria.

Nederlandse Geloofsbelydenis, s.a. 'Psalmboek, Gereformeerde Kerke van SuidAfrika, NG-Kerk Uitgewers, Pretoria.

Osborne, G.R., 2010, Exegetical Commentary on the New Testament, Matthew, Zondervan, Grand Rapids.

Patania, S.S., 1998, 'Ethical issues in clinical practice', in D.M. Aronstein \& B.J. Thompson (eds.), HIV and Social Work. A Practitioner's Guide, pp. 247-267, The Harrington Park Press, New York.

Peels, H.G.L., 1996, 'Het Woord is leven - over de Heilige Schrift', in G. Van Den Brink, M. Van Campen \& J. Van Der Graaf (reds.), Gegrond geloof. Kernpunten
uit de geloofsleer, in Bijbels, historisch en belijdend perspectief, pp. 52-93, uit de geloofsleer, in Bijbels,
Boekencentrum, Zoetemeer.

Pienaar, A., 2011, 'Vigs al hoe meer onder ouer mense', Beeld, 30 November, p. 9.

Pieterse, H.J.C., 1989, 'Tussen hemel en aarde. Refleksies oor nuwe vorme van spiritualiteit', Praktiese Teologie in Suid Afrika 4(2), 48-56.

Smit, D.J., 1982, 'Enkele teologiese opmerkings rondom die pyn-verskynsel', in D.W. De Villiers \& J.A.S. Anthonissen (eds.), Dominee en dokter by die siekbed, pp. 46-50, NG-Kerk-Uitgewers, Kaapstad.

Sunderland, R.H. \& Shelp, E.E., 1987, AIDS. A manual for pastoral care, The Westminster Press, The Westminster Press, Philadelphia.

Swindoll, C.R., 1999, Bron van my hoop, Struik Christelike Boeke, Kaapstad.

UNAIDS (Global Report) 2010, AIDS epidemic update, viewed 31 October 2011, from www.unaids.org

Van de Brake, N., Tielens, D., De Bruijn, L., \& Thiadens, A., 1974, Sterven bij het leven Krisisverwerking als stervensbegeleiding, Uitgeverij Bosch \& Keuning, Baarn.

Van Dyk, A., 2008, HIV/AIDS care and counseling. A multidisciplinary approach, 4th edn., Pearson Education South Africa, Cape Town.

Velema, W.H., 1990, Nieuw zicht op gereformeerde spiritualiteit, Uitgeverij J. H. Kok, Kampen.

Velema, W.H., 1994, Pastoraat met raad en daad, Uitgeverij J.H. Kok, Kampen.

Venter, C., 1996, Vitkringende Liefdesbetoon. Kommunikatiewe handelinge in diens van die onderlinge liefdesgemeenskap in die kerk, RGN, Pretoria.

Venter, C.J.H., 1972, 'By die sterfbed. Die pastorale dimensie in die begeleiding van sterwendes', Th.M.-verhandeling, PU vir CHO, Potchefstroom.

Venter, C.J.H., 1999, 'Die spiritualiteit van die bedienaar met verwysing na sy toerustingstaak', In die Skriflig 33(2), 187-200.

Venter, H.P., 1979, Pastoral care of the terminally ill patient and the family, University Microfilms International, London.

WCC (World Council of Churches), 1997, Facing Aids. The challenge, the churches' response. A WCC Study Document, WCC Publications, Geneva.

Whiteside, A. \& Sunter, C., 2000, AIDS. The challenge for South Africa, Human \& Rousseau, Cape Town.

Winiarski, M.G., 2004, Community-based counselling for people affected by HIV and AIDS, Longman, Windhoek.

Wright, N.T., 2006, Simply Christian. Why Christianity makes sense, Harper-Collins Publishers, New York. 